YАK $323(4 / 9)$

ББК $66.3(4 / 8)$

DOI 10.22394/1682-2358-2020-4-24-30

V.A. Butenko, Assistant, post-graduate student of the Comparative Politics Department, Peoples' Friendship University of Russia

\section{IMMIGRANT INTEGRATION POLICY TRANSFORMATION IN DENMARK}

Features of Denmark's immigrant integration policy are considered. The evolution of Danish integration legislation and public discursive practices that have a direct impact on the immigrant integration policy is analyzed.

Key words and word-combinations: Denmark, migration, immigrant integration policy.
В.А. Бутенко, ассистент, аспирант кафедрь срабнительной политологии Российского университета дружбь народов (email: vladislav_butenko@list.ru)

\section{ТРАНСФОРМАЦИЯ ИНТЕГРАЦИОННОЙ ПОАИТИКИ ААНИИ}

Аннотация. Рассматриваются особенности интеграционной политики Дании. Анализируется эволюция датского интеграционного законодательства и общественных дискурсивных практик, оказывающих непосредственное влияние на вырабатываемую политику в области интеграции иммигрантов и беженцев.

Ключевые слова и словосочетания: Дания, миграция, интеграционная политика.

M ный Аля всех исторических эпох. ОАнако в XXI в. миграция стама одним из самых обсуждаемых вопросов. Усимение миграционных потоков в 2010-2011 и 2015-2016 гг. в европейские страны укрепияо позиции правых и популистских политических партий, призывающих к ограничению потока иммигрантов и бежкенцев. В стороне не остались и скандинавские государства. В Аании, приверженной наиболее ограничитемьной миграционной и интеграционной политике среАи стран СканАинавии, Аискурс стал смещаться правее. Помитика в области интеграции иммигрантов также претерпела изменения, что связано с за-

24 Bulletin of the Volga Region Institute of Administration • 2020. Vol. 20. № 4 
креплением партийно-политического мандшафта с доминирующей ролью правоцентристов. Следует отметить, что подобные трансформации обусмовлены моделью государства всеобщего благоденствия, основанной на отборе новых потенциальных соџиальных субъектов Аля сохранения ее устойчивости [1] .

Ао Второй мировой войны Аания представляла собой относительно однородное по этническому составу общество. Переход к многонациональному и полиэтническому государству был заложен в 1960-е годы, что было вызвано потребностью датской наџиональной экономики в рабочей силе. В силу проАолжающегося экономического бума и реализаџии модели «welfare state» экономика страны нуждалась в трудовых мигрантах [2], основная доля которых прибывала из Турџии, Пакистана и Югославии.

В 1973-1974 гг. на фоне энергетического кризиса в Европе датские профсоюзы и организации работодателей приняли решение о приостановмении приема трудовых мигрантов. ОАнако данное правило не касалось беженцев, которые приезжали в основном из Чили, Вьетнама, Афганистана, Ирана, Ирака и Сирии. Усимение миграционных потоков привело к тому, что в 1980 г. в стране насчитывалось порядка 3\% иммигрантов и их потомков [3, p. 12].

По состоянию на 1 января 2019 г. численность населения Аании составмяет 5,8 мин человек, из которых 793,6 тыс. человек - иммигранты и их потомки (13,7\% от общего числа проживающих в стране) [3, р. 7]. Аве трети иммигрантов и их потомков явмяются выходџами из незападных стран", преимущественно из Турџии, Сирии, Ирака, Аивана, Пакистана, Боснии и Герцеговины, Ирана, Сомали, Афганистана и Вьетнама [3, р. 6] .

Сушественные размичия имеются при сравнении демографического и соџиально-экономического состава коренных датчан и иммигрантов и их потомков. В структуре населения численность миџ старше 65 мет среди коренных граждан составцяет $21 \%$, в то время как среди иммигрантов из незападных стран - 7\%. Аоля физических миџ младше 25 мет среди иммигрантов и их потомков - 80\% [4], в связи с чем возникает вопрос об их интеграции.

Аатское законодательство в сфере соџиокультурной интеграции мигрантов претерпело наиболее существенные изменения среди скандинавских стран. Аания одной из первых европейских стран присоединилась к Женевской конвенции о беженџах 1951 г. ОАнако с 1990-х годов Аатское интеграционное законодательство несколько раз пересматривалось и ужесточалось, часто из-за увеличения числа прибывающих и роста антииммигрантских политических настроений в обществе.

Основными нормативно-правовыми актами, опредемяющими датскую интеграционную политику, явмяются Закон об иностранцах, принятый в 1983 г., и Закон об интеграџии, принятый в 1998 г. Оба закона не единожды пере-

\footnotetext{
* Под незападными странами в настоящей статье понимаются все страны, кроме госуАарств - чиенов ЕС, Исландии, Норвегии, Великобритании, Швейџарии, Аихтенштейна, Андорры, Монако, Сан-Марино, Канады, США, Австралии и Новой Зеландии.
} 
сматривались. В частности, в Закон об иностранцах было внесено более ста поправок [5] .

В 2001 г. правым альянсом Аиберальной партии (Венстре) и Консервативной народной партии при подАержке Аатской народной партии было учреждено Министерство по декам беженџев, иммигрантов и интеграџии. Основные задачи Министерства заключались в ограничении числа иммигрантов и бежкенцев, введении более жестких требований Аля получения постоянного места жительства и гражданства, содействии культурной интеграции в Аатское общество [6].

В 2011 г. новая правительственная коалищия Социал-демократической партии, Аатской соџиал-либеральной партии и Соџиалистической народной партии киквидировала Министерство по делам бежкенџев, иммигрантов и интеграции, перераспределив обязанности межАу несколькими министерствами и ведомствами $[7$, с. 120].

Следует подчеркнуть, что Аания одна из первых в Европе разработала закон, регламентирующий порядок интеграции иммигрантов и беженцев. Иммиграционная службба определяет муниџипалитет, в котором в течение трех мет будет проживать бежкенец, таким образом «полностью контролируя политику рассемения беженџев» [8, р. 329]. При этом именно на муниципалитет возмагается основная ответственность за интеграцию иммигрантов и беженцев. В частности, муниципалитеты реализуют вводные программы (introduktionsprogrammer), предназначенные для беженџев, и программы интеграции (integrationsprogrammer), рассчитанные на Аругие категории мигрантов.

В Аании действует дифференцированный подход к программам интеграции. Содержание таких программ детерминировано потребностями датского рынка труда. Часто участники программ интеграции дважды в неделю работают в качестве практикантов или стажеров, а в иные дни посещают курсы языковой подготовки и овладевают знаниями о датских этнокультурных ценностях. Кроме того, программы, ориентированные на беженџев, имеют различия в зависимости от потребностей и уровня их образования. Так, Амя беженца с более высокой квалификацией программа интеграции может Алиться один гоА, после чего Аиџо получает возможность дополнительно заниматься языковой подготовкой посме работы. Аیя беженца с низкой квалификацией (40\% иммигрантов из незападных стран имеют только школьное образование) длительность программы может составцять пять мет.

Важным условием при принятии иммигрантов и беженцев является обязательное подписание ими договора об интеграџии. Иммигрантам и беженџам «предлагается подтвердить свою готовность соблюдать датское законодательство, уважать демократические принџипы, изучать датский язык, признавать принципы гендерного равенства, уважать свободу совести и свободу слова...» [9, р. 11] . В договоре об интеграции детально прописываются цели программы (например, получение работы или образования), а также конкретные действия, которые следует выполнять иммигранту или беженцу. В случае не- 
выполнения тех или иных условий к иммигранту или беженцу применяются штрафные санкции [10].

Вопросы миграции и интеграции, поднимавшиеся с конџа 1960-х годов, Аовоцьно часто касались искцючительно иммигрантов и беженџев из незапаАных стран. В публичном дискурсе до сих пор Аоминирует мнение о слабой интеграции выходџев из преимущественно мусульманских стран; по Аанной причине подчеркивается высокий уровень безработиџы среди физических киџ, принадлежащих к Аанной категории, и неприятие Аатских культурных ценностей [11, с. 135] .

Привлечение рабочей симы дмя создания государства всеобщего благосостояния в Аании предполагались временное пребывание трудовых мигрантов и их обратная эмиграция в страны исхода [12]. ОАнако этого не случилось, и трудовые мигранты из незападных стран, в отличие от иммигрантов из сосеАних скандинавских государств, остацись в Аании.

С 1990-х годов попумярность приобрела конщепщия этнической принадлежности. Нередко понятие этнической принадлежности приобретает негативную коннотацию и применяется к иммигрантам и беженџам из незападных стран [13]. Термин «этнический» воспринимается как некий Аевиант или вызов датским культурным ценностям, в то время как термин «национальный», относящийся к выходџам из западных государств, культурным вызовом не является [14, р. 63]. Следовательно, происходит конструирование «других» [15]. При этом концептуализация общенациональных ценностей рассматривается как инструментально необходимая дия поддержания функционирования демократического правового общества. В целом можно констатировать факт политизации национальной культуры и идентичности, поскольку вопрос жизнеспособности государства определяется сквозь призму сощиокуиьтурной идентичности [16, р. 73] .

В период национацьного миграционного кризиса (ици кризиса беженцев), пиковой точкой которого явцяются 2015-2016 гг., в общественном Аискурсе вопрос об интеграции в датское общество прибывающих мигрантов был поставлен более остро. В частности, новость о гибели в Средиземном море сотен беженщев в датских СМИ была названа следствием миберальной политики Европейского Союза: «Европейские политики несут совместную ответственность за то, что происходит... Они не смогли ужесточить иммиграџионное законодательство таким образом, чтобы... было ясно, что нельзя получить виА на жительство в Европе искмючительно по экономическим причинам» [17] . Более того, если шведские средства массовой информации часто описывали миграционный кризис как межлународную трагедию, то датские СМИ - как национацьную проблему [18, р. 11] .

За три месяца до парламентских выборов, в марте 2019 г., миграционное и интеграционное законодательство претерпели существенные изменения. В частности, были усилены правовые нормы в законах об иностранцах и об интеграции. Новые законодательные нормы касаются в первую очередь помитики интеграции и управления миграџией, особенно при акџентировании внимания на иммигрантах и беженцах из незападных стран. В целом данные 
изменения стали кульминационным моментом в Авижении к более ограничительной интеграционной политике.

Во-первых, в Аании было законодательно закреплено, что вид на жительство для беженцев будет выдаваться временно [19]. Аанная норма преАполагает, что при изменении ситуации в стране, откуда прибыл беженец, в благоприятную сторону, ему следует покинуть страну. Во-вторых, термин «интеграционное пособие» заменяется в нормативно-правовых актах на «самообеспечение» [20]. В настоящий момент бежкенџы, проживающие на тер-

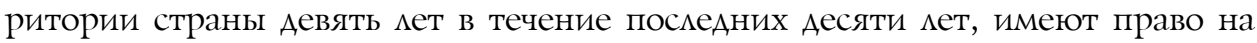
получение государственной финансовой помощи. При этом миџа, пребывающие в королевстве в течение короткого промежутка времени, права на финансовую помощь не имеют. Вместо этого последние до недавних поправок могли рассчитывать на интеграционное пособие, которое в настоящее время стало именоваться «самообеспечением», что предполагает ответственность самих бежкенцев за интеграцию.

Ограничительные меры в области национальной интеграционной политики получили название «САвиг парадигмы». Необходимо отметить, что данные меры были выдвинуты Аатской народной партией, позиции которой в стране усиливаются, и подАержаны Соџиал-демократической партией. Кроме того, Аатской народной партией были предложены 146 мер жесткой экономии, предусматривающие пограничный контроль; ограничение свободы вероисповедания Аля оказания вцияния на политический ислам; криминализацию бездомных; поощрение добровольного возвращения бежкенцев в страны исхода и т.A. [20].

Аидер датской соџиал-демократии Метте Фредериксен в свое время заявмяла, что в случае неужесточения государственной интеграционной политики она покинет пост премьер-министра страны. Тем не менее после побеАы на выборах социал-демократы так и не предприняли попыток коренного реформирования интеграционной политики. Но риторика, которая ранее именовалась радикально правой, в настоящее время явцяется скорее мейнстримной.

ГАавным проводником ограничительных мер в сфере интеграционной политики выступает Аатская народная партия. С момента своего зарождения она позиџионирует себя в качестве партии наџионалистов и патриотов [21, с. 67]. Аатская народная партия приобрела вес среАи избирателей: если на парламентских выборах 1998 г. ей удалось получить 7,4\% голосов, 2011 г. - 12,3\%, то выборы 2015 г. принесли партии 21,1\% голосов. Невзирая на

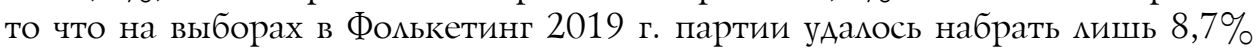
голосов, она смогла закрепить свои позиции и получить шестнадцать мест в парламенте.

Вместе с тем наиболее радикацьными политическими партиями, сконцентрированными искмючительно на вопросах миграции и интеграџии, явцяются «Новые правые» и «Жесткий курс», которые не рассматривают экономические программы «САвиг парадигмы» и «146 мер жесткой экономии» как эффективные меры в сфере миграционной политики. Во 
время предвыборной кампании 2019 г. политической партией «Новые правые» был репрезентован набор требований под названием «СправеАмивая миграџионная политика». КАючевые требования сводятся к полному прекращению предоставления убежища, самообеспечению иностранных граждан, их депортации в случае совершения преступления. По результатам парламентских выборов 2019 г. политическая партия «Новые правые» набрала 2,4\% голосов, что дало ей возможность войти в Фолькетинг $[22$, с. 44$]$.

Партия «Жесткий курс» выступает с резкой радикальной риторикой в отношении иммигрантов из мусульманских стран, подчеркивая «невозможность их интегращии» в датское общество. Политическая партия подвергает сомнению Аояльность мусульманских иммигрантов к национальному государству и западным традициям, образу жизни, ценностям и т.А., рассматривая их как демографическую угрозу самому существованию датской нации [23, p. 277] . Важным вопросом, который поднимается партией «Жесткий курс», является вопрос идентичности. Национальная сплоченность, по мнению партийного руководства, зиждется на этнической, Аингвистической, культурной, религиозной однородности. Несмотря на радикализаџию общественного дискурса в Аании, партии «Жесткий курс» по итогам выборов 2019 г. не удаАось войти в пармамент [23, р. 277].

Проведенный анализ свидетельствует о смещении интеграционной поАитики Аании вправо. Такой сАвиг находит подАержку не только среАи маргинальных партий, но и со стороны политических партий, находящихся во власти Алительный период, например Соџиал-демократической партии Аании. Этнокультурное разнообразие, являвшееся основой интеграционной политики в 1980-1990-е годы, постепенно заменяется требованием миграџионной ассимицяџии. Интеграџионная политика Аании становится все более ограничительной и делает основной упор на необходимости иммигрантов и беженцев обеспечивать себя самостоятемьно, изучать датский язык и культуру, уважать основные ценности демократического правового государства.

\section{Библиографический список}

1. Tjelmeland H., Brochmann G. I globaliseringens tid 1940-2000 // Norsk innvandringshistorie. Bd. 3 / ed. by K. Kjeldstadli. Oslo: Pax, 2003.

2. Kampen mod ledigheden: to besvarelser af Rockwool Fondens priskonkurrence om en analyse af ledighedsproblemet i Danmark / ed. by K. Albæk. København: Spektrum, 1992.

3. Integration. Status og udvikling 2019. Fokus på ikke-vestlige lande / Udlændinge-og Integrationsministeriet // Integrationsbarometer. URL: https://integrationsbarometer.dk/tal-og-analyser/ filer-tal-og-analyser/integration-status-og-udvikling-filer/integration-status-og-udvikling-2019.

4. Det nationale integrationsbarometer // Udlændinge-og Integrationsministeriet. 2018. URL: https://integrationsbarometer.dk.

5. Jensen J. Position paper. Copenhagen: The Ministry of the Interior, 2012.

6. Hedetoft $U$. Denmark: Integrating Immigrants into a Homogeneous Welfare State // Migration Policy Institute. 01.11.2006. URL: https://www.migrationpolicy.org/article/denmark-integratingimmigrants-homogeneous-welfare-state. 
7. Бабынина Л.О. Дания // Современная Европа. 2016. № 2 (68). С. 120-123.

8. Myrberg G. Local Challenges and National Concerns: Municipal Level Responses to National Refugee Settlement Policies in Denmark and Sweden // International Review of Administrative Sciences. 2017. Vol. 83 (2). P. 322-339.

9. Mouritsen P., Hovmark Jensen C. Integration Policies in Denmark. INTERACT Research Report 2014/06. 2014. URL: http://cadmus.eui.eu/bitstream/handle/1814/32020/INTERACT-RR2014_06.pdf?sequence $=1$

10. Lov om integration af udlændinge i Danmark (integrationsloven) nr. 474 af 01.07.1998// Social jura. URL: http://www.socialjura.dk/content-storage/love/love/integrationslov

11. Волков А.М. Миграционные потоки в страны Северной Европы // Вестник Дипломатической академии МИД России. Россия и мир. 2020. № 1 (23). С. 126-142.

12. Würtz Sørensen J. Velkommen Mustafa? Debatten om Gæstearbejderne og det Danske Samfund i Starten af 1970'erne. Åarhus: Åarhus Universitet, Center for Kulturforskning, Working Paper. 1988. № 17.

13. Schierup C.U. På kulturens slagmark. Esbjerg: Syddansk Universitetsforlag, 1993.

14. Jensen S.Q. Othering, Identity Formation and Agency // Qualitative Studies. 2011. Vol. 2 (2). P. 63-78.

15. Hervik P. The Danish Cultural World of Unbridgeable Differences // Ethnos. 2004. Vol. 69 (2). P. 247-267.

16. Mouritsen P. The Particular Universalism of a Nordic Civic Nation. Common Values, State Religion and Islam in Danish Political Culture // Multiculturalism, Muslims and Citizenship: A European Approach / ed. by T. Modood, A. Triandafyllidou, R. Zapata-Berrero. London: Routledge, 2006. P. 70-93.

17. Godhedens pris // Jyllands-Posten. 21.04.2015. URL: https://jyllands-posten.dk/debat/leder/ ECE7641085/Godhedens-pris

18. Hagelund A. After the Refugee Crisis: Public Discourse and Policy Change in Denmark, Norway and Sweden // Comparative Migration Studies. 2020. Vol. 13 (8). URL: https://doi.org/10.1186/ s40878-019-0169-8

19. Udlændingeloven nr. 226 af 08.06.1983 // Social jura. URL: http://www.socialjura.dk/content-storage/love/love/udlaendingelov

20. To nye på listen: 146 udlændinge-stramninger siden 2015 // Dit overblik. 06.05.2019. URL: https://ditoverblik.dk/to-nye-paa-listen-146-udlaendinge-stramninger-siden-2015

21. Плевако Н.С. Национализм и правый популизм в скандинавских странах и Финляндии // Научно-аналитический вестник Института Европы РАН. 2018. № 3. С. 63-69.

22. Плевако Н.С. Парламентские выборы в Дании // Научно-аналитический вестник Института Европы РАН. 2019. № 3 (9). С. 42-48.

23. Dorling $D$. Slowdown: The End of the Great Acceleration - and Why It's Good for the Planet, the Economy, and Our Lives. London: Yale University Press, 2020. 